\title{
Quality of "urda" obtained after production of montenegrin semi-hard cheese
}

\author{
${ }^{1 *}$ Bojanic Rasovic, M., ${ }^{1}$ Nikolić, N. and ${ }^{2}$ Rasovic, R. \\ ${ }^{1}$ University of Montenegro, Biotechnical faculty, Mihaila Lalića 1, Podgorica, Montenegro \\ ${ }^{2}$ ZZ "Cijevna”, Ljajkovići, Zeta, Podgorica, Montenegro
}

\begin{abstract}
Article history:
Received: 1 July 2017

Received in revised form:

15 July 2017

Accepted: 15 July 2017

Available Online: 16 July

2017
\end{abstract}

Keywords:

Urda,

Albumin cheese,

Whey,

Technology,

Montenegro

DOI:

http://doi.org/10.26656/

fr.2017.5.107

\begin{abstract}
"Urda" cheese is one of the dairy products with a long tradition of production in mountainous areas in Montenegro. It is mainly used for its own use, fresh and unsalted, but can be kept for a longer period in "kaca" (vat) and consumed as a mature "urda". Knowing the quality and technology of production of urda is significant regarding its nutritional and biological value, as well as in terms of its standardization, the preservation of traditional technology and the protection of geographic origin. Because of that, we examined the urda production technology in the artisanal conditions as well as the chemical composition of 14 urda samples from different production batches. Production of urda was done in a traditional manner with less modification. The results showed significant variations in the chemical composition of the tested samples. The mean value of dry matter content was $42.85 \%$, fat content $21.74 \%$, protein content $13.66 \%$, salt content $2.67 \%$, fat content in dry matter $50.77 \%$, free fat dry matter content $21.11 \%$ and water content in free fat dry matter $49.67 \%$. Due to significant statistical differences in the chemical parameters of investigated urda samples, it can be concluded that standardization of urda quality and technology has to be done.
\end{abstract}

\section{Introduction}

"Urda" cheese is a dairy product with a long tradition of production in mountainous areas in Montenegro. In the countries of the former Yugoslavia, it is still called "skuta", "furda", "hurda", "bjelava", "cvarog", "provara". The name of the "provara" best describes this product because during the preparation of this product milk whey cooked - "provari". In Bulgaria, it is called the "izvara", in Italy "riccota" (Baković, 1959). The word "riccota" in Italian means a re-cooked or twice the cooked, indicating that the riccota is obtained by cooking acidified milk whey. It can be obtained from whey or a mix of whey and milk (El-Sheikh et al., 2010). The production of urda is based on warming the whey and separating its proteins. Temperature $85-90^{\circ} \mathrm{C}$ leads to denaturation of protein, mainly albumin, and globulin, which float on the surface and retain the fat droplets remaining after cheese production. Whey proteins make for approximately $18-20 \%$ of total milk proteins (Antunac et al., 2011). They are easy to digest and have a high level of utilization in the body, which causes high nutritional value. Partial protein denaturation at $\mathrm{T} 70^{\circ} \mathrm{C}$ to $90-95^{0} \mathrm{C}$ does not diminish their nutritional value but makes them more readily accessible to the digestive enzymes (Tratnik, 1998). These proteins have a positive effect on health. They enhance immunity, inhibit HIV, have anti-cancer effect against colon cancer (El-Sheikh et al., 2010). Beneficial affect the intestinal flora and promote liver regeneration, due to the high content of the amino acid with sulfur. Due to high biological value and pleasant taste "urda" could have a significant place in the assortment of industrial production (Bilyk et al., 2017). Due to variations in quality due to uneven production technology, use of urda in Montenegro is limited. She is prepared in a traditional manner from the sheep's, bovine, or a mixture of sheep's and bovine milk. It was mostly used for own use, fresh and unsalted, but can be kept for a longer period of time in vats (Dozet et al., 1996; Dozet et al., 2004). Acidification of Istria and Pag "skuta" is achieved by the addition of sour whey in an amount up to $10 \%$, vinegar or citric acid (Antunac et al., 2011). Protein whey can be extracted by adding 3\% of whey vinegar or sour whey and warming to boiling (Jovanović and Obradović, 1950). In the Carpathians, urda is traditionally produced from sheep's whey (Bilyk 
et al., 2017). During the production of Sicilian sheep's "riccota", $5-15 \%$ of sheep's milk is added in order to increase the quantity and improve the product characteristics (Mancuso et al., 2014). Riccota cheese is obtained by heating and acidification of whey $\left(85-90^{\circ} \mathrm{C}\right)$ with lactic and citric acid for the purpose of whey protein coagulation (Kamel et al., 2013). Riccota has a shortterm usage due to high humidity and $\mathrm{pH}$ above 6. During production, high standards of hygiene and maintenance of cold chains must be provided during distribution (Mancuso et al., 2014). Knowing the quality and the way of producing "urda" is significant in terms of its nutritional and biological value, as well as in terms of standardization, preservation of traditional production technology and protection of geographic origin. The quality of urda is influenced by many factors, such as type and quality of milk, cheese production technology, urda production technology etc. The standardized and geographically protected product would become one of the recognizable national brands of Montenegro and as such would have a great social and economic significance. In that goal, we examined traditional "urda" production technology in Montenegro as well as its chemical composition.

\section{Material and methods}

\subsection{Milk for production of semi-hard cheese}

Pasteurized bovine milk used for the production of semi-hard cheese had an average fat content of 3.80\%, protein $3.28 \%$, lactose $4.34 \%$ and total dry matter content 8.34\% (Bojanić Rašović et al., 2013).

\subsection{Whey for urda production}

Whey for the production of urda was obtained in the process of production of semi-hard cow's cheese, whose production technology, chemical composition and rheological properties have been described (Bojanić Rašović et al., 2012; Bojanić Rašović et al., 2013). Milk whey used for the production of urda had the average value of dry matter of $6.99 \%$ (Bojanic Rasovic et al., 2013). In fresh whey was added the acidic whey from the previous day and in sometimes a smaller amount of milk.

\subsection{Production of urda}

Urda was produced in mini cheese factory "Cijevna" with a daily production capacity of $1000 \mathrm{~L}$, in a traditional way with fewer modifications (Dozet et al., 1996). The whey was gradually heated to $85^{\circ} \mathrm{C}$ for about $1 \mathrm{~h}$ with occasional stirring. At the end of the heating, the was added $\mathrm{NaCl}$. After extraction on the surface, the curd was allowed to cool. After cooling, it was collected with a large spoon, placed in a canvas bag and left to squeezing 10-14h. It is then packed in plastic boxes of $250 \mathrm{~g}$ to $500 \mathrm{~g}$ and stored at refrigerator temperature for up to 3 to 4 days.

\subsection{Chemical analysis of urda}

The chemical composition of 14 samples of urda from different production batches was made in the dairy laboratories of the Biotechnical Faculty of the University of Montenegro. The tests were performed on the Milcoscan FT 120 apparatus and were determined by: fat content, protein content, dry matter content and salt content. Calculated is content of free fat dry matter, water content, water content in dry matter and fat content in dry matter of "urda". The water content in the dry matter was calculated according to the following formula: DMWF x 100 / DM (DMWF - free fat dry matter, DM - dry matter). The fat content in the dry matter of the cheese was calculated according to the following formula: F x 100 / DM (F - content of fat, DM - content of dry matter). The following statistical parameters were determined: mean value, maximum and minimum value and standard deviation (by using Microsoft Office Excel Program 2007). Classification of urda samples in relation to the content of dry matter and fat content was done according to the Regulations (12).

\section{Results}

The results shown in Table 1 show that the maximum value for fat content was $35.65 \%$, a minimum of $15.85 \%$ and a mean $21.74 \%$; the maximum value for the protein content was $17.53 \%$, a minimum of $9.55 \%$ and a mean of $13.66 \%$; the maximum value for dry matter content was $52.25 \%$, minimum $36.14 \%$, and medium $42.85 \%$; the maximum value for salt content was $3.08 \%$, minimum 2.17 and medium $2.67 \%$; maximum water content was $63.86 \%$, minimum $47.75 \%$, and mean $56.97 \%$. The standard deviation for fat content was 5.86 , protein content 2.14 , dry matter content 4.83 , salt content 0.24 and water content 4.83 .

The results shown in Table 2 show that the maximum value for fat content in dry matter was $68.22 \%$, minimum $41.82 \%$ and mean $50.16 \%$; maximum value for free fat dry matter was $25.83 \%$, minimum $15.73 \%$, and mean $21.11 \%$; maximum value for water content in free fat dry matter was $58.17 \%$, minimum $31.77 \%$ and mean $49.67 \%$. The standard deviation for fat content in dry matter was 8.38 , for the content of free fat dry matter 2,78 and for water content in free fat dry 
Table 1. Results examination of the chemical composition of the urda

\begin{tabular}{cccccc}
\hline $\begin{array}{c}\text { Sample } \\
\text { mark }\end{array}$ & $\begin{array}{c}\text { Amount of fat } \\
(\%)\end{array}$ & $\begin{array}{c}\text { Amount of protein } \\
(\%)\end{array}$ & $\begin{array}{c}\text { Amount of dry } \\
\text { matter }(\%)\end{array}$ & $\begin{array}{c}\text { Amount of salt } \\
(\%)\end{array}$ & $\begin{array}{c}\text { Amount of water } \\
(\%)\end{array}$ \\
\hline $50 / 06$ & 24.84 & 12.55 & 44.25 & 2.56 & 55.75 \\
$51 / 06$ & 22.35 & 17.53 & 48.18 & 2,84 & 51.82 \\
$49 / 06$ & 35.65 & 11.2 & 52.25 & 2.17 & 47.75 \\
$48 / 06$ & 28.31 & 9.55 & 44.04 & 2.5 & 55.96 \\
$45 / 06$ & 21.86 & 15.28 & 43.96 & 2.55 & 56.04 \\
$47 / 06$ & 19.19 & 16.05 & 42.11 & 2.55 & 57.89 \\
$52 / 06$ & 21.48 & 15.61 & 45.42 & 2.8 & 54.58 \\
$44 / 06$ & 28.76 & 13.68 & 48.52 & 2.33 & 51.48 \\
$42 / 06$ & 15.84 & 13.67 & 37.48 & 2.77 & 62.52 \\
$43 / 06$ & 16.15 & 12.1 & 36.49 & 2.93 & 63.51 \\
$41 / 06$ & 19.74 & 14.98 & 42.77 & 2.84 & 57.23 \\
$40 / 06$ & 16.9 & 14.44 & 40.41 & 2.89 & 59.59 \\
$39 / 06$ & 16.87 & 12.43 & 38.01 & 3.08 & 61.99 \\
$46 / 06$ & 16.51 & 12.19 & 36.14 & 2.65 & 63.86 \\
X & 21.74 & 13.66 & 42.85 & 2.67 & 56.97 \\
Max & 35.65 & 17.53 & 52.25 & 3.08 & 63.86 \\
Min & 15.84 & 9.55 & 36.14 & 2.17 & 47.75 \\
SD & 5.86 & 2.14 & 4.83 & 0.24 & 4.83 \\
\hline
\end{tabular}

matter 8.73. According to the criterion of Regulations (12) for cheeses with ripening, four examined samples of urda belong to extra-hard and extra fatty cheeses, six to hard and fatty, one to semi hard and fatty and three to semi-hard and three-quarter fatty cheeses.

\section{Discussion}

Montenegrin urda is a dairy product white to whitegreyish color, a form of finely crushed cheese. Taste is specific (Dozet et al., 1996; Dozet et al., 2004). The "skuta" produced on the Dalmatian islands is also white with weak transitions on grayish-yellow, specific taste, soft consistency (Baković, 1959), as well as Istria skuta (Antunac et al., 2011). The "urda" in our experiments is also white to white stain, finely granular, soft, lubricating consistency, pleasant and specific smell and taste, as defined by the Regulations (12). The maximum value for free fat dry matter of tested urda samples was $25.83 \%$, minimum $15.73 \%$ and mean value $21.11 \%$. Of the tested 14 samples of urda, 5 samples (35.71\%) not corresponded to the requirements of the Regulations (12, 13), according to which lowest content of fat free dry matter should be at least 20\% (Table 2). Differences in chemical composition of investigated urda samples were statistically significant. The standard deviation for fat content in dry matter was 8.38 , for the content of free fat dry matter 2.78 and for water content in free fat dry matter 8.73 (Table 2). Rakočević (1952) has determined the average fat content in the fresh montenegrin urda of $16.52 \%$, the fat content in dry matter $35.3 \%$ and the water content of $53.2 \%$; The Dalmatian skuta has $26.4 \%$ water, $35.4 \%$ fat, $37.0 \%$ fat in dry matter (Baković, 1959); Serbo-Macedonian skuta has $29.95 \%$ water, $11.70 \%$ fat and $31.99 \%$ fat in dry matter (Šipka and Raković, 1951); "Bračka skuta" contains 38.03\% dry matter, $24.93 \%$ fat, $9.70 \%$ protein and $3.70 \%$ lactose on average (Rako et al., 2016). "Bovška skuta" has $8.29 \%$ water, $8.50 \%$ fat, $16.55 \%$ fat in dry matter (Sabadoš, 1960a). The fat content in "Istria skuta" is of $28.90 \%$ and the fat content in dry matter of $64.47 \%$; in "Pag skuta" fat content is $23.25 \%$ and fat content in dry matter $59.65 \%$. The physico-chemical composition of skuta is variable, due to the mode and conditions of production and squeezing. Differences in the amount of fat occur due to differences in raw material quality and cheese making technology. In the smaller cheese grain, a larger amount of fat is transferred into the whey, which then passes to the skuta. Without the standardization of fat in raw material for skuta production, uniformity of composition of skuta cannot be expected (Antunac et al., 2011). According to the Regulations (12) cheeses of milk, whey belongs to fresh cheeses and are marketed under the name crumbly cheese or skuta. If matures, urda 
Table 2. Classification of urda samples according to fat content in dry matter

\begin{tabular}{|c|c|c|c|c|c|c|}
\hline $\begin{array}{l}\text { Sample } \\
\text { mark }\end{array}$ & $\begin{array}{c}\text { Fat } \\
\text { content in } \\
\text { dry matter } \\
(\%)\end{array}$ & $\begin{array}{l}\text { Content } \\
\text { of free fat } \\
\text { dry matter } \\
\quad(\%)\end{array}$ & $\begin{array}{l}\text { Water } \\
\text { content in } \\
\text { free fat } \\
\text { dry matter } \\
(\%)\end{array}$ & $\begin{array}{c}\text { Classification } \\
\text { according to the water } \\
\text { content in free fat dry } \\
\text { matter according to the } \\
\text { Regulations of the } \\
\text { SFRY (12) } \\
\end{array}$ & $\begin{array}{c}\text { Classification } \\
\text { according to fat content } \\
\text { in the dry matter of } \\
\text { cheese according to the } \\
\text { Regulations of the } \\
\text { SFRY (12) }\end{array}$ & $\begin{array}{l}\text { Classification } \\
\text { according to the } \\
\text { content of fat in dry } \\
\text { matter of cheese } \\
\text { according to RS (13) }\end{array}$ \\
\hline $50 / 06$ & 56.13 & 19.41 & 43.86 & Extra hard & Extra fatty & Whey cream cheese \\
\hline $51 / 06$ & 46.38 & 25.83 & 53.61 & hard & fatty & Whey cream cheese \\
\hline $49 / 06$ & 68.22 & 16.6 & 31.77 & Extra hard & Extra fatty & Whey cream cheese \\
\hline $48 / 06$ & 64.28 & 15.73 & 35.71 & Extra hard & Extra fatty & Whey cream cheese \\
\hline $45 / 06$ & 49.72 & 22.10 & 50.27 & hard & fatty & Whey cream cheese \\
\hline $47 / 06$ & 45.57 & 22.92 & 54.42 & hard & fatty & Whey cream cheese \\
\hline $52 / 06$ & 47.29 & 23.94 & 52.70 & hard & fatty & Whey cream cheese \\
\hline $44 / 06$ & 59.27 & 19.76 & 40.72 & Extra hard & Extra fatty & Whey cream cheese \\
\hline $42 / 06$ & 42.26 & 21.64 & 57.73 & semi hard & $\begin{array}{l}\text { Three-quarter fatty } \\
\text { cheese }\end{array}$ & Whey cream cheese \\
\hline $43 / 06$ & 45.21 & 20.34 & 55.74 & hard & fatty & Whey cream cheese \\
\hline $41 / 06$ & 46.15 & 23,03 & 53.84 & hard & fatty & Whey cream cheese \\
\hline $40 / 06$ & 41.82 & 23.51 & 58.17 & semi hard & $\begin{array}{l}\text { Three-quarter fatty } \\
\text { cheese }\end{array}$ & Whey cream cheese \\
\hline $39 / 06$ & 44.38 & 21.14 & 55.61 & semi hard & $\begin{array}{l}\text { Three-quarter fatty } \\
\text { cheese }\end{array}$ & Whey cream cheese \\
\hline $46 / 06$ & 45.68 & 19.63 & 54.31 & semi hard & fatty & Whey cream cheese \\
\hline$X$ & 50.16 & 21.11 & 49.67 & & & \\
\hline Max & 68.22 & 25.83 & 58.17 & & & \\
\hline Min & 41.82 & 15.73 & 31.77 & & & \\
\hline SD & 8.38 & 2.78 & 8.73 & & & \\
\hline
\end{tabular}

gets characteristic features and is put on the market as a mature cheese or mature skuta or urda. According to the criteria of the Regulations (12) for cheeses with ripening, the four examined samples of urda belong to extra-hard and extrafatty cheeses, six to hard and fatty, one to semihard and fatty and three to semi-hard and three-quarter fatty cheeses (Table 2) In the group of extrafatty skuta belong to "dalmatinska", "grobnička" and "bohinjska skuta"; in the group of fatty skuta belongs "bovška skuta". In the group of lowfat belongs a "pirotska skuta". However, within these groups, there are variations (Sabadoš, 1960b). According to the Regulation (13) all examined samples of urda can be classified into whey cream cheese because contain more than $33 \%$ fat (Table 2).

\section{Conclusion}

Urda obtained from whey extracted after the production of montenegrin semi-hard cheese had a similar chemical composition as the urda obtained in cheese factory and households in the surrounding countries. The significant statistical difference in the chemical composition of urda samples was determined. Therefore, it is necessary to work on the standardization of raw material quality and urda production technology for the purpose of its placement on the market and the protection of geographical origin as an indigenous product from Montenegro.

\section{Acknowledgements}

We thank the Ministry of Science of Montenegro for support of this paper through the financing of the national project: "Isolation and characterization of autochthonous lactic acid bacteria to be used for the production of specific cheeses in Montenegro"- No 49/2008). 


\section{References}

Antunac, N., Hudik, S., Mikulec, N., Maletić, M., Horvat, I., Radeljević, B. and Havranek, J. (2011). Proizvodnja i kemijski sastav Istarske iPaške skute. Mljekarstvo, 61(4), 326-335.

Baković, D. (1959). Skuta. Mljekarstvo, 9(8), 172-177.

Bilyk, O., Slyvka, N., Gutyj, B., Dronyk, H. and Sukhorska, O. (2017). Study of different ways of proteins extraction from sheep and cow whey for "urda" cheese production, report on research projects, EUREKA: Life Sciences, 3, 3-8.

Bojanić Rašović, M., Martinović, A., Nikolić, N., Katić, V. and Rašović, R. (2012). Chemical and rheological properties of semihard cheese during ripening, Proceedings of the First international symposium on animal science, 8-10 november, $p$. 1023-1035. Belgrade, Serbia.

Bojanić Rašović, M., Nikolić, N., Martinović, A., Katić, V., Rašović, R., Walzer, M. and Domig, K. (2013). Correlation between protein to fat ratio of milk and chemical parameters and the yield of semi-hard cheese, Biotechnology in Animal Husbandry, 29(1), 145-159, ISSN 1450-9156.

Dozet, N., Adžić, N., Stanišić, M. and Živić, N. (1996). Autohtoni mlječni proizvodi. Poljoprivredni institut Podgorica, Silmir, Beograd, p 1-238.

Dozet, N., Maćej, O. and Jovanović, S. (2004). Autohtoni mliječni proizvodi osnova za razvoj specifičnih originalnih mliječnih prerađevina $u$ savremenim uslovima. Biotechnology in Animal Husbandry, 20(3-4), 31-48.

El-Sheikh, M., Farrag, A. and Zaghloul, A. (2010). Ricotta Cheese from Whey Protein Concentrate. Journal of American Science, 6(8), 321-325.

Jovanović, A. and Obradović, D. (1950). Mljekarstvo, priručnik za poljoprivredne i stočarske tehnikume, p. 1-354.

Kamel, B., Boubaker, K. and Attia, H. (2013). Implementation of ricotta cheese production process in Tunisia. International Food Research Journal, 20(5), 2343-2348.

Mancuso, I., Cardamone, C., Fiorenza, G., Macalus, G., Arcuri, L., Miraglia, V. and Scatassa, M.L. (2014). Sensory and microbiological evaluation of traditional ovine ricotta cheese in modified atmosphere packaging, Italian Journal of Food Safety, 3, 122-124.

Pravilnik o kvalitetu mleka, proizvoda od mleka, sirila i čistih kultura ( Sl. list SFRJ br. 51/82, 39/89 i 58/94).
Pravilnik o kvalitetu proizvoda od mleka i starter kultura Republike Srbije ("Sl. glasnik RS“, br. 33/2010, 69/2010, 43/2013 i i 34/2014).

Rako, A., Kalit, S. and Tudor Kalit, M. (2016). Hranjiva vrijednost i potrošačka prihvatljivost bračke skute. 51st Croatian and 11th 360 Proceedings 51st Croatian and 11th International Symposium on Agriculture, p. 360-363. Opatija. Croatia

Rakočević, M. (1952). Mljekarstvo na Sinjajevini i mjere za njegovo unapređenje. Stočarstvo, Zagreb, 3.

Sabadoš, D. (1958). Bohinjska skuta, Mljekarstvo, Zagreb, 5, 98-107.

Sabadoš, D. (1960a). Bovška skuta. Mljekarstvo, 2, 2534.

Sabadoš, D. (1960b). Klasifikacija jugoslavenske skute. Mljekarstvo, 3, 49-51.

Tratnik, Lj. (1998). Mlijeko - Tehnologija, biokemija i mikrobiologija. Hrvatska mljekarska udruga. Zagreb, 30-70, 345-379. 